\title{
PENGARUH PERCEIVED SERVICE QUALITY TERHADAP REPURCHASE DAN CUSTOMER SATISFACTION SEBAGAI VARIABEL INTERVENING PADA FAST FOOD RESTAURANT DI SURABAYA
}

\author{
Jocellynne Saintz \\ Fakultas Ekonomi, Universitas Kristen Petra, Jl. Siwalankerto 121-131, Surabaya \\ E-mail: jocellynne97@gmail.com
}

\begin{abstract}
Abstrak:Penelitian ini membahas pengaruh Perceived service quality terhadap Repurchase dan customer satisfaction sebagai variabel intervening di Fast food restaurant. Sampel penelitian ini berjumlah 100 responden pelanggan Fast food restaurant yang pernah melakukan transaksi dalam enam bulan terakhir. Pengukuran dilakukan dari variabel Perceivedservice quality (X1) dengan indikator Reliability, Responsiveness, Assurance, Empathy, Tangible, variabel customer satisfaction (Y1) dengan indikator Fulfillment, Pleasure, Ambivalence, sedangkan Repurchase (Z1) memiliki indikator Interest, Pleasure-based value, Sign value, Risk probability, dan Risk. Hasil penelitian ini menunjukkan bahwa: (1) Perceived service quality berpengaruh signifikan terhadap customer satisfaction; (2) Perceivedservice quality berpengaruh signifikan terhadap Repurchase; (3) Customer satisfaction berpengaruh signifikan terhadap Repurchase.
\end{abstract}

Kata kunci: Perceived Service Quality, Customer Satisfaction, Repurchase.

\begin{abstract}
The purpose of this research aims to analyze the effects of Perceived Service Quality towards Repurchase with Customer Satisfaction as an intervening variabel inFast food restaurant. This research was conducted by distributing questionnaires to 100 respondents who were customers of Fast food restaurants who had made transactions in the last six month. This research use the Perceived service quality (XI) variable with the indicators Reliability, Responsiveness, Assurance, Empathy, Tangible, Customer satisfaction variable (Y1) with the indicators Fulfillment, Pleasure, Ambivalance, Repurchase variable (Z1) with the indicators Interest, Pleasure-based value, Sign value, Risk Pribability, dan Risk. The results show: (1) Perceived service quality influence significantly effect customer satisfaction; (2) Perceived service quality affect significantly effect repurchase; (3) customer satisfaction has a significant impact on repurchase.
\end{abstract}

Keywords: Perceived Service Quality, Customer Satisfaction, Repurchase.

\section{PENDAHULUAN}

Keberlangsungan hidup manusia bergantung pada berbagai kebutuhan, baik secara fisik maupun psikis yang dapat menunjukan kehidupan manusia dengan baik. (Kotler 2009, p. 51) Teori Hirarki Kebutuhan Maslow mengungkapkan bahwa terdapat lima tahapan kebutuhan manusia, yaitu basic needs, safety needs, social needs, self-esteem needs dan self actualization needs. Dimana basic needs adalah kebutuhan akan makanan yang merupakan kebutuhan paling dasar sebelum memasuki tahap kebutuhan selanjutnya.

Usaha kuliner saat ini mendapatkan banyak perhatian dari masyarakat, sehingga tidak heran jika banyak pelaku bisnis yang membuka dan mencoba berbisnis kuliner untuk mendapatkan keuntungan besar. Perkembangan ini disebabkan karena munculnya gaya hidup masyarakat yang cenderung untuk mengkonsumsi makanan di luar rumah dan mencoba makanan yang baru. Banyaknya pilihan restoran yang ada membuat konsumen cenderung untuk melakukan transaksi dengan restoran yang mampu memberikan keuntungan dan manfaat positif, agar konsumen merasa puas setelah bertransaksi.
Kualitas jasa harus dimulai dari kebutuhan pelanggan dan berakhir dengan kepuasaan pelanggan serta persepsi positif terhadap kualitas jasa (Tjiptono, 2006). Dimana kualitas jasa merupakan ukuran dari seberapa bagus tingkat layanan yang diberikan sesuai dengan ekspektasi pelanggan. Semakin konsisten pelayanan yang diberikan dan semakin terpenuhinya ekpektasi maupun harapan pelanggan, maka pelanggan akan menciptakan persepsi yang baik pula terhadap kualitas restoran yang telah diterimanya.

(Tjiptono, 1997) Tujuan suatu bisnis adalah untuk menciptakan rasa puas untuk pelanggan. Kualitas jasa yang unggul dan konsisten dapat menumbuhkan kepuasaan pelanggan dan dapat memberikan manfaat lebih terhadap perusahaan seperti hubungan yang harmonis antara pelanggan dan perusahaan, membentuk persepsi yang bisa menjadi dasar terjadinya pembelian ulang, membentuk rekomendasi dari mulut ke mulut (word of mouth) yang dapat menguntungkan perusahaan dan bahkan dapat menciptakan reputasi perusahaan baik dimata pelanggan.

Repurchase atau pembelian kembali adalah bagaimana konsumen pernah melakukan pembelian pertama yang ternyata ekpektasi dan harapannya terpenuhi, sehingga menciptakan kepuasaan terhadap 
restoran tersebut. Adanya rasa kepuasaan inilah yang menjadi dasar adanya pembelian kembali.

Melihat adanya globalisasi yang terjadi, dan banyaknya budaya-budaya asing yang masuk ke Indonesia, membuat masyarakat Indonesia menerima dengan baik hal-hal tersebut. Dengan adanya fenomena ini, peneliti ingin melihat apa penyebab masyarakat untuk melakukan pembelian kembali dalam mengkonsumsi makanan di Fast food restaurant.

Berdasarkan latar belakang diatas, maka permasalahan yang ditimbulkan adalah apakah Perceived service quality mempunyai pengaruh yang positif terhadap Repurchase dan Customer satisfaction sebagai variabel interveningnya.

\section{LANDASAN TEORI}

\section{Perceived Service Quality}

Hanif Mauludin (2004) mendefinisikan "kualitas pelayanan sebagai hasil persepsi dari perbandingan antara harapan pelanggan dengan kinerja aktual pelayanan" dengan kata lain ada dua faktor utama yang mempengaruhi, yaitu expected service (yang diharapkan) dan perceived service (yang didapatkan). (Kotler, 2006, p. 139). Melalui pengertian diatas dapat disimpulkan bahwa Perceived quality merupakan persepsi yang ditentukan secara objektif. Persepsi pelanggan juga melibatkan apa yang penting bagi pelanggan karena setiap pelanggan memiliki kepentingan yang berbeda-beda terhadap suatu jasa atau produk.

Parasuraman (1988) mengungkapkan bahwa terdapat lima dimensi dari kualitas layanan, yaitu:
1. Tangibles
2. Reliability
3. Responsiveness
4. Assurance
5. Empathy

\section{Customer Satisfaction}

Customer satisfaction telah diakui dalam ilmu pemasaran dan telah dipraktekan sebagai salah satu tujuan utama dari aktivitas-aktivitas bisnis (Wang, Y. and Lo, HP., 2002). Maka, dapat disimpulkan bahwa kepuasaan pelanggan merupakan elemen penting dari tujuan berbisnis, karena kepuasaan pelanggan akan membawakan banyak efek yang menguntungkan dalam jangka panjang. "Kepuasaan pelanggan didefinisikan sebagai kondisi terpenuhinya semua kebutuhan sesuai dengan harapan ketika mengkonsumsi sebuah produk.Berdasarkan pendapat ini, dapat dijelaskan bahwa terdapat dua komponen utama untuk menciptakan sebuah kepuasaan pada pelanggan, yaitu harapan pelanggan dan realisasi layanan" Gerson (2004, p. 5). Dengan adanya definisi ini dapat disimpulkan bahwa kepuasaan pelanggan akan muncul jika harapannya dapat dipenuhi melalui pelayanan yang baik. Jika keinginan dan kebutuhan pelanggan dapat terpenuhi maka dengan sendirinya kepuasaan pelanggan akan muncul.

Menurut Arnould et al., 2004 customer satisfaction dapat diukur dari dimensi-dimensi berikut ini:

1. Fulfillment

2. Pleasure

3. Ambivalence

\section{Repurchase}

Menurut Meuraxa (2008) pembelian ulang atau repurchase adalah pembelian yang berkelanjutan atas suatu produk sebagai hasil dari evaluasi konsumen terhadap pengalaman konsumsi dan menghasilkan keputusan untuk menggunakannya secara teratur.

Guthrie dan Kim (2009) mengukur keterlibatan konsumen kedalam lima dimensi sebagai berikut:

1. Interest

2. Pleasure-based value

3. Sign value

4. Risk probability

5. Risk

\section{Model Penelitian}

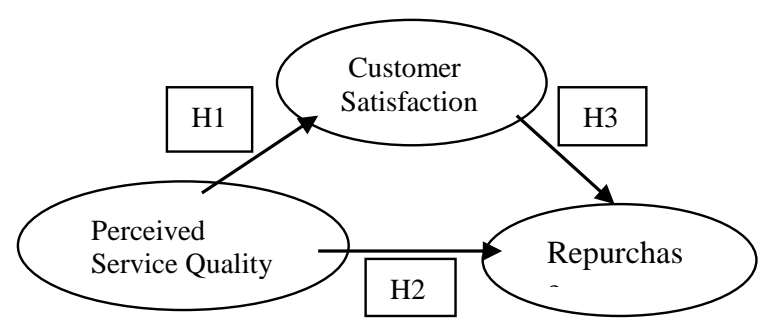

Gambar 1. Model Penelitian

\section{Hipotesa}

H1: Terdapat pengaruh perceived service quality pada customer satisfaction di Fast food restaurant

$\mathrm{H} 2$ : Terdapat pengaruh perceived service quality pada repurchase di Fast food restaurant

H3: Terdapat pengaruh customer satisfaction pada repurchase di Fast food restaurant

\section{METODOLOGI PENELITIAN}

\section{Populasi}

Menurut Cooper Emory (1996, p. 214), "populasi adalah seluruh kumpulan elemen yang dapat kita 
gunakan untuk membuat kesimpulan". Populasi dalam penelitian ini adalah seluruh konsumen di Fast food restaurant

\section{Sampel}

Sampel adalah bagian dari jumlah dan karakteristik yang dimiliki oleh populasi tersebut (Malhotra 2008, p. 116).Metode sampel yang digunakan dalam penelitian ini adalah metode purposive sampling, yaitu teknik pengambilan sampel dengan pertimbangan tertentu (Sugiyono, 2014). Peneliti melakukan penelitian untuk memilih anggota populasi yang merupakan pelanggan Fast food restaurant yang memiliki kriteria, seperti pelanggan pernah bertransaksi dalam enam bulan terakhir di Fast food restaurant.

\section{Definisi Operasional Variabel}

\section{PerceivedService Quality $\left(\mathrm{X}_{1}\right)$}

a) Reliability

Kemampuan karyawan untuk melaksanakan layanan yang dijanjikan secara akurat dan terpercaya kepada pelanggan restoran.

b) Responsiveness

Kemampuan karyawan untuk membantu dan memberikan jasa dengan cepat kepada pelanggan restoran.

c) Assurance

Merupakan kesopanan dan pengetahuan pelayan, juga kemampuan mereka untuk menimbulkan kepercayaan dan keyakinan pada pihak restoran.

d) Empathy

Kepedulian dan perhatian secara pribadi kepada pelanggan Fast food restaurant.

e) Tangible

Penampilan fisik, fasilitas yang diberikan dari Fast food restaurant.

Customer Satisfaction $\left(\mathrm{Y}_{1}\right)$

a) Satisfaction as pleasure.

Pleasure menunjukan hubungan yang positif antara Fast food restaurant dengan pelanggan.

b) Satisfaction as fulfillment.

Fulfillment merupakan pemenuhan kebutuhan pelanggan dalam mencapai suatu kepuasaan.

c) Satisfaction as ambivalence.

Ambivalence merupakan perasaan unik yang dirasakan pelanggan saat bertransaksi dengan Fast food restaurant.

\section{Repurchase $\left(\mathrm{Z}_{1}\right)$}

1. Interest

Merupakan ketertarikan konsumen pada pembelian suatu produk.

\section{Pleasure value}

Berhubungan dengan perasaan senang yang dirasakan konsumen saat melakukan pembelian produk.

3. Sign value

Dimana produk yang dibeli dapat memberikan nilai prestis kepada penggunannya.

4. Risk probability

Keterlibatan konsumen dalam keberanian mengambil sebuah resiko dalam memilih suatu produk.

\section{Risk}

Kemungkinan risiko yang harus ditanggung konsumen atas pembelian suatu produk.

\section{ALAT ANALISA}

\section{Path Analysis}

Penelitian menggunakan structural equation modeling (SEM) berbasis partial least square (PLS) untuk menjawab rumusan masalah. Partial least square (PLS) pertama kali digunakan untuk metode umum dalam mengestimasi path model yang menggunakan konstruk laten dan multiple indikator didalamnya. Partial least square (PLS) untuk menguji suatu teori yang lemah dan masalah pada asumsi normalitas distribusi data (Jogiyanto, 2008).

\section{T-test}

Di dalam penelitian ini terdapat variabel intervening yaitu penghubung antara variabel dependen dan variabel independen. Pengujian hipotesis mediasi (variabel intervening) dapat dilakukan dengan prosedur $t$-test. Pengujian t-test digunakan untuk mendapatkan nilai t-statistik yang diperlukan apabila peneliti ingin melakukan uji hipotesis, sehingga peneliti dapat mengatakan pengaruh sebuah variabel dapat dikatakan memiliki pengaruh yang signifikan atau tidak. T-test dilakukan dengan menggunakan metode bootstrapping.

Metode bootstrappingadalah suatu proses pengujian re-samplingyang dilakukan oleh sistem komputer untuk mengukur akurasi pada sampleestimate. Bootstraping digunakan untuk mengukur akurasi pada sample. Apabila nilai bootstrap lebih dari (>) 1.96 maka dinyatakan bahwa variabel tersebut memiliki pengaruh yang signifikan sedangkan apabila nilai bootstrap lebih rendah $(<)$ dari 1.96, maka dinyatakan pengaruh variabel tersebut lemah (Abdillah \& Hartono, 2015).

\section{Statistik deskriptif}

Statistik deskriptif digunakan untuk menyajikan data secara deskriptif yang menggambarkan karakteristik responden serta jawaban-jawaban responden 
sehingga mampu digunakan sebagai kesimpulan dari hasil kuisioner yang sudah disebarkan selama penelitian ini.

\section{ANALISA DAN PEMBAHASAN}

\section{Analisa Deskriptif}

Tabel 1. Analisa Deskriptif Dimensi Tamgibles

\begin{tabular}{lccccccc}
\hline \multirow{2}{*}{ Indikator } & \multicolumn{9}{c}{ Jawaban } & \multirow{2}{*}{ Mean } & \multirow{2}{*}{ Std. dev } \\
\cline { 2 - 7 } & STS & TS & N & S & SS & & \\
\hline X1.01 & 0 & 3 & 3 & 51 & 43 & 4.34 & 0.681 \\
X1.02 & 0 & 4 & 5 & 41 & 50 & 4.37 & 0.757 \\
X1.03 & 0 & 4 & 3 & 29 & 64 & 4.53 & 0.741 \\
X1.04 & 0 & 3 & 8 & 42 & 47 & 4.33 & 0.749 \\
X1.05 & 0 & 3 & 5 & 39 & 53 & 4.42 & 0.724 \\
\hline
\end{tabular}

Tabel diatas memiliki pernyataan XI.01 yang memiliki nilai mean sebesar 4.34 dengan nilai simpang (standar deviasi) sebesar 0.681 yang artinya bahwa secara umum responden setuju bahwa Fast food restaurant memiliki kebersihan dalam peralatan makanan yang disediakan.

Pernyataan XI.02 memiliki nilai mean sebesar 4.37 dengan nilai simpang sebesar 0.757 yang artinya sebagian responden setuju bahwa Fast food restaurant memperhatikan kelengkapan peraltan di meja makan (tusuk gigi, tissue, sauce). Begitu pula XI.03 yang memiliki nilai mean 4.53 dengan standar deviasi sebesar 0.741, hal ini menunjukan bahwa responden setuju dengan desain eksterior dari Fast food restaurant memang menarik. Sedangkan XI.04 yang memiliki mean sebesar 4.33 dengan standar deviasi 0.749, menunjukan bahwa responden juga setuju dengan desain interior dari Fast food restaurant yang membuat nyaman mereka. Dan XI.05 menunjukan nilai mean sebesar 4.42 dan nilai standar deviasi sebesar 0.724, dengan demikian menunjukan bahwa responden setuju bahwa karyawan Fast food restaurant rapi dalam berpenampilan.

Tabel 2. Analisa deskriptif dimensi Ambivalence

\begin{tabular}{|c|c|c|c|c|c|c|c|}
\hline \multirow{2}{*}{ Indikator } & \multicolumn{5}{|c|}{ Jawaban } & \multirow{2}{*}{ Mean } & \multirow{2}{*}{ Std. dev } \\
\hline & STS & TS & $\mathrm{N}$ & $\mathrm{S}$ & SS & & \\
\hline Y1.03 & 0 & 2 & 23 & 35 & 40 & 4.13 & 0.833 \\
\hline
\end{tabular}

Pernyataan bahwa Y1.03 memiliki mean sebesar 4.13 dan standar deviasi sebesar 0.833 yang menunjukan bahwa responden dapat memahami pelayanan yang lambat saat di Fast food restaurant sebagai konsekuensi saat restoran penuh.

Tabel 3. Analisa deskriptif dimensiInterest

\begin{tabular}{|c|c|c|c|c|c|c|c|}
\hline \multirow{2}{*}{ Indikator } & \multicolumn{5}{|c|}{ Jawaban } & \multirow{2}{*}{ Mean } & \multirow{2}{*}{ Std. dev } \\
\hline & STS & $\mathrm{TS}$ & $\mathrm{N}$ & $\mathrm{S}$ & SS & & \\
\hline Z1.01 & 0 & 1 & 17 & 38 & 44 & 4.25 & 0.766 \\
\hline
\end{tabular}

Pernyataan Z1.01 memiliki mean sebesar 4.25 dan standar deviasi sebesar 0.766 yang dimana hal ini membuktikan bahwa pelanggan tertarik untuk melakukan pembelian kembali terhadap varian produk Fast food restaurant.

\section{Evaluasi Path Coefficient dan Coefficient of deter- mination}

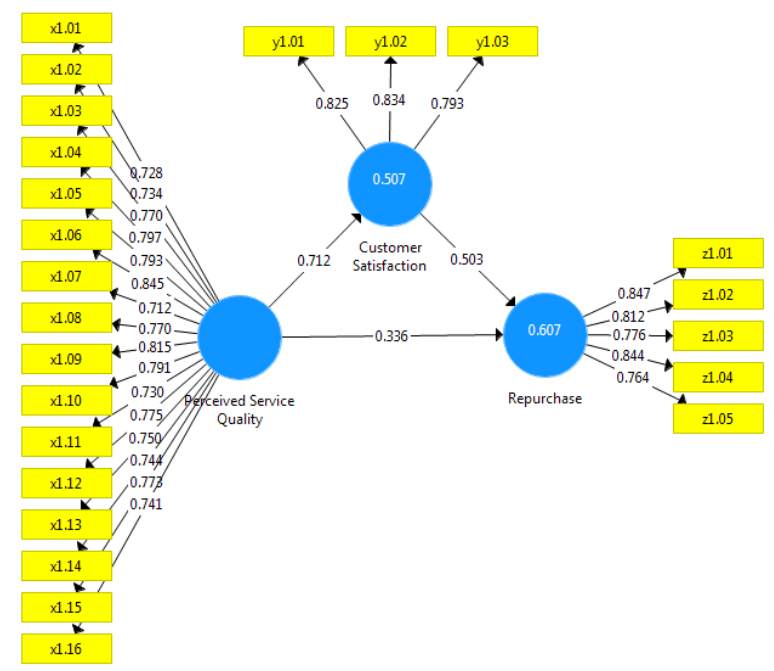

Gambar 2.Path Coefficient dan Coefficient of determination

Pada analisa path coefficient ini telah terbukti bahwa customer satisfaction merupakan variable intervening yang memperkuat hubungan antara perceived service quality dengan repurchase sebesar 0.358 . Nilai ini didapatkan dari hasil perkalian antara 0.712 dan 0.503 .

Nilai coefficient of determination $\left(\mathrm{R}^{2}\right)$ yang di dalam gambar ditunjukan pada angka di dalam lingkaran customer satisfaction yang dipengaruhi oleh Perceived service quality sebesar 0.507. Artinya variable perceived service quality mempengaruhi customer satisfaction sebesar $50.7 \%$ sedangkan 49.3\% lainnya dipengaruhi oleh variable lain di luar penelitian. Lalu variable repurchase yang dipengaruhi oleh perceived service quality sebesar 0.607. Artinya variable perceivedservice quality mempengaruhi repurchase sebesar $60.7 \%$ sedangkan $39.3 \%$ lainnya dipengaruhi oleh variable lain di luar penelitian.

\section{T-statistic}

T-statistic pada pengaruh perceived service quality terhadap customer satisfaction menunjukan 17.570 yang artinya perceivedservice quality berpengaruh signifikan terhadap customer satisfaction. $T$ statistic pada pengaruh perceivedservice quality terhadap repurchase menunjukan 2.989 yang artinya 
perceived service quality berpengaruh signifikan terhadap repurchase. T-statistic pada customer satisfaction terhadap repurchase menunjukan 5.960 yang artinya customer satisfaction berpengaruh signifikan terhadap repurchase.

\section{PEMBAHASAN}

\section{Perceived Service Quality terhadap Customer Satis- faction}

Penelitian ini mempunyai hasil bahwa Perceived service quality Fast food restaurant memiliki pengaruh yang signifikan terhadap customer satisfaction dengan nilai uji T-statistic > 1.96, yaitu 17.570.

Penelitian ini mempunyai hasil yang menunjukkan bahwa bahwa perceived service quality mempunyai pengaruh yang signifikan terhadap emotional satisfaction, dimana hasil ini sesuai dengan teori-teori yang sudah ada, bahwa semakin baik dan berkualitas service atau jasa yang diberikan maka semakin tinggi juga tingkat kepuasaan konsumen yang didapat. Hasil penelitian ini memiliki hasil yang sama dengan penelitian yang dilakukan oleh Saif Ullah Malik (2012) yang dimana penelitiannya menyatakan bahwa persepsi kualitas layanan berpegaruh secara signifikan dan positif terhadap kepuasaan pelanggan. Dimana Saif Ullah Malik juga berpendapat bahwa jika ingin meningkatkan kepuasaan pelanggan, maka hal yang perlu dievaluasi adalah dengan terus mempertahankan kualitas jasa atau layanan yang diberikan atau bahkan harus selalu ditingkatkan agar dapat membentuk dan mempengaruhi persepsi pelanggan mengenai kualitas kinerja layanan yang baik sehingga dapat berkorelasi dengan tingkat kepuasaan pelaggan.

Dari hasil penelitian ini dapat dibuktikan dan disimpulkan bahwa persepsi kualitas layanan yang dimiiki konsumen terhadap Fast food restaurant memiliki pengaruh yang besar dalam membangun tingkat kepuasaan pelanggan. Dengan adanya kualitas layanan yang baik dan dapat memenuhi harapan dan ekspektasi mereka, sebuah restoran dapat menimbulkan persepsi yang baik dari konsumen, oleh karena itu persepsi pelanggan mengenai kualitas jasa dan layanan memiliki pengaruh yang signifikan dan dapat mempengaruhi kepuasaan pelanggan untuk menjadi dasar adanya keputusan pembelian kembali bahkan menjadi pelanggan setia. Persepsi kualitas layanan merupakan tahap awal dalam sebuah proses pembelian. Setelah adanya tahap percobaan atau pembelian pertama, maka konsumen akan memahami dengan baik atau mengevaluasi apakah restoran tersebut dapat memenuhi kebutuhan dan keinginannya sesuai dengan ekpektasi. Jika restoran dapat meme- nuhi harapan pelanggan maka akan membentuk suatu hasil evaluasi dari konsumen yang nantinya dapat memberikan efek secara positif dan negatif dalam waktu jangka panjang.

\section{Perceived Service Quality terhadap Repurchase}

Penelitian ini memiliki hasil bahwa perceived service quality Fast food restaurant memiliki pengaruh terhadap repurchase secara signifikan dengan nilai uji T-statistic > 1.96, yaitu 2.989 .

Penelitian ini mempunyai hasil yang menunjukkan bahwa bahwa perceived service quality mempunyai pengaruh langsung yang signifikan terhadap repurchase, dimana hal ini sesuai dengan teori-teori yang ada bahwa salah satu elemen penting yang membuat konsumen melakukan pembelian kembali adalah ketika konsumen mempunyai persepsi yang baik mengenai kualitas layanan brand tersebut. Adanya keputusan pembelian kembali oleh pelanggan bisa disebabkan dengan adanya persepsi yang kuat dan baik yang telah dievaluasi oleh pelanggan pada pembelian pertama, yang kemudian bisa menjadi dasar keputusan pembelian selanjutnya dan dapat memberikan dampak positif lainnya kepada restoran tersebut. Konsumen harus mempunyai persepsi yang baik mengenai brand yang dicobanya, karena jika konsumen memiliki persepsi dan pengalaman yang baik maka konsumen akan dengan mudah melakukan pembelian kembali secara terus menerus dan dapat menjadi alat promosi secara gratis bagi perusahaan.

Hasil penelitian ini mempunyai hasil yang sesuai dengan pendapat oleh (Meirani Harsani, Anfas, 2015) (Dr. Mohammad Reza Ebrahimi, Sara Tootoonkavan, 2014) dimana persepsi kualitas layanan pelanggan yang baik mempunyai hubungan yang berpengaruh dalam membuat pengambilan keputusan pembelian kembali. Dengan adanya evaluasi oleh konsumen, maka persepsi yang tertanam pada konsumen baik positif maupun negatif akan membantu konsumen dalam mengingat pengalaman baik yang pernah terjadi dan dirasakan sebelumnya, sehingga pengalaman dan persepi pelanggan akan menjadi dasar adanya keputusan pembelian kembali atau bahkan tidak akan ada pembelian selanjutnya dari konsumen. Oleh karena itu kualitas layanan harus diberikan sebaik mungkin kepada pelanggan karena tanpa kita sadari semakin banyak pesaing yang muncul yang bisa menjadi pilihan dari konsumen dalam bertransaksi, sehingga konsumen akan memilih untuk bertransaksi dengan restoran yang dapat memenuhi harapan dan yang sesuai antara biaya yang dibayarkan dan manfaat yang diterimanya.

Dalam membangun sebuah persepsi kualitas layanan terdapat beberapa hal yang harus diperhatikan 
Fast food restaurant, seperti bangunan restoran yang dapat menarik konsumen untuk datang dan mencoba, keadaan interior yang nyaman, pencahayaan terang dan bersih yang bisa membuat konsumen betah untuk makan dan merasa aman akan kualitas kebersihannya, kerapian karyawan Fast food restaurant yang harus selalu rapi sehingga lebih enak untuk dilihat dan kualitas makanan dan minuman yang ditawarkan harus sesuai dengan harga yang ditawarkan, sehingga sesuai dengan apa yang diharapkan konsumen.

\section{Customer Satisfaction terhadap Repurchase}

Penelitian ini memiliki hasil bahwa Customer satisfaction memiliki pengaruh yang signifikan terhadap repurchase karena nilai uji T-statistic yang didapat > 1,96, yaitu 5.960 .

Penelitian ini mempunyai hasil yang menunjukkan bahwa bahwa customer satisfaction mempunyai pengaruh yang signifikan dan positif terhadap repurchase, dimana hal ini sesuai dengan hasil penelitian yang sudah ada bahwa salah satu elemen yang membuat konsumen melakukan pembelian kembali adalah ketika konsumen merasa puas terhadap brand tersebut. Hasil penelitian ini mempunyai hasil yang sesuai dengan pendapat oleh (Meirani Harsani, Anfas, 2015) dimana adanya keputusan pembelian kemballi para pelanggan dipengaruhi dan didasari oleh adanya hasil evaluasi pelanggan pada pembelian sebelumnya yang terbentuk menjadi persepsi kualitas layanan pelanggan, dimana persepsi yang ada adalah sebuah gambaran dari kepuasaan konsumen dan pelanggan, yang bisa menjadi dasar adanya keputusan pembelian kembali bahkan seterusnya. Kualitas layanan yang diberikan kepada pelanggan untuk dirasakan ketika pembelian pertama atau sebelumnya dapat menjadi dasar terbentuknya kepuasan dan dapat mempengaruhi secara langsung keputusan untuk melakukan pembelian kembali.

Dalam penelitian ini dapat dibuktikan dan disimpulkan bahwa Fast food restaurant dapat memberikan kualitas layanan yang sesuai dengan harapan pelanggan, karena menurut data yang ada bahwa ternyata hampir seluruh konsumen merasa puas terhadap restoran tersebut dalam pemenuhan kebutuhan dan keinginan dari pelanggan. Setelah pelanggan mendapatkan kebutuhan makanan dan minuman sesuai dengan keinginan mereka, maka pelanggan akan membentuk rasa puas tersebut karena terpenuhinya kebutuhan dan keinginanya. Dewasa ini, menciptakan kepuasaan pelanggan merupakan hal yang harus diperhatikan oleh perusahaan. Karena ketika konsumen merasa puas terhadap brand tersebut maka akan memberikan dampak yang sangat baik dalam berbagai hal, seperti adanya keputusan pembelian kembali, promosi secara gratis melalui word of mouth bahkan bisa menjadi pelanggan setia Fast food restaurant.

\section{KESIMPULAN DAN SARAN}

\section{Kesimpulan}

Penelitian diatas dapat dilihat bahwa variabelvariabel tersebut memiliki pengaruh antara satu dengan variabel lainnya.Perceived service quality terhadap customer satisfaction, perceived service quality terhadap repurchase, dan customer satisfaction terhadap repurchase.

Seluruh variabel ini menunjukan suatu pengaruh, berdasarkan path coefficient menunjukan bahwa dalam penelitian ini customer satisfaction memperkuat hubungan antara variabel independen yang merupakan perceived service quality terhadap variabel dependen yang merupakan repurchase. Hubungan antara variabel independen dengan dependen dihubungkan melalui variabel intervening.

\section{Saran}

Untuk menjaga adanya pembelian kembali oleh konsumen, maka Fast food restaurant perlu lebih menjaga persepsi kualitas layanan dengan cara menjaga kualitas makanan dari bahan makanan dan kebersihan peralatan makanan yang digunakan agar kualitasnya dapat dipertahankan bahkan dapat ditingkatkan. Selain itu Fast food restaurant juga hendaknya menjaga fasilitas dan kondisi fisik restoran seperti mendekorasi interior sesuai dengan event-event tertentu, tujuannya adalah agar pelanggan mendapat suasana baru.

Selain kondisi fisik baik interior maupun eksterior, kualitas dan kemampuan karyawan juga harus ditingkatkan dengan cara mengikutsertakan karyawan dalam pelatihan agar dapat meningkatkan ketrampilan agar kemampuan bekerja mereka dapat lebih baik lagi dalam melayani konsumen.

\section{DAFTAR PUSTAKA}

Abdillah, W., \& Hartono, J. (2015). Partial Least Square (PLS) - Alternatif Structural Equation Modeling (SEM) dalam Penelitian Bisnis (Cetakan 1). Yogyakarta: Penerbit Andi.

Arnould, E., Price, L., \& Zinkhan, G. (2004). Consumer 2nd ed. Boston, Massachusetts: The McGraw-Hill Companies.

Cooper dan Emory, (1996). Metode Penelitian Bisnis, Jakarta: Erlangga.

Gerson, R. F. (2004). Mengukur Kepuasan Pelanggan. Jakarta:PPM.

Guthrie, M., dan Kim, S. (2009), The Relationship BetweenConsumer Involment and Brand per- 
ceptions of Female Cosmetic Consumers. Journal of Brand Management. 17(2).

Hanif Mauludin. (2004). Essay: Analisis Kualitas Pelayanan, pengaruhnya terhadap Citra (Image) Rumah Sakit.

Harsasi, M., Anfas. (2015). The Impact of Perceived Service Quality on Repurchase: A Study of A Distance Education Institution.

Jogiyanto. (2008). Metodologi penlitian sistem informasi. Yogyakarta: Andi Yogyakarta.

Kotler, P. \& Keller, K. L. (2006). Marketing Management $\left(12^{\text {th }}\right.$ edition). Upper Saddle River: Pearson Education, Inc.

Kotler, Philip. (2009). Manajemen Pemasaran. Jakarta: Erlangga.

Malhotra, Y., Galletta, D. F., \& Kirsch, L. J. (2008). Howendogenous motivations influence user intentions Beyond the dichotomy of extrinsic and intrinsic usermotivations. Journal of Management Information Systems, 25(1), pp. 267-299.

Mohammad Reza Ebrahimi, Sara Tootoonkavan. (2014). Investigating The Effect of Perceived Service Quality, Perceived Value, Brand Image, Trust, Customer Satisfaction on Repurchase Intention and Recommendation to Other Case Study: LG Company.
Meuraxa, Nurfaizah. (2008). Analisis Pengaruh Sosial (Social Influence) terhadap kecenderungan Pembelian Kembali (Repurchase), Fakultas Ekonomi danilmu social UIN Syarif Hidayatullah. Jakarta.

Parasuraman, A., Zeithaml, V. \& 1l. (1988). SERVQUAL: Amultiple-item scale for measuring consumer perceptions of service quality. Journal of retailing, VI, 12-40

Saif, U, M. (2012). Customer Satisfaction, Perceived Service Quality and Mediating Role of Perceived Value. International Journal of Marketing Studies.

Sugiyono. (2014). Metode Penelitian Pendidikan Pendekatan Kuantitatif, Kualitatif Dan $R \& D$. Bandung: Alfabeta.

Tjiptono, Fandy, (1997), Strategi Pemasaran, Penerbit: Andi Offset, Edisi Kedua, Cetakan Pertama, Yogyakarta.

Tjiptono, Fandy, (2006). Manajemen Jasa. Edisi Pertama. Yogyakarta: Andi

Y. Wang, H.P. Lo. (2002), Service quality, customer satisfaction andbehavior intentions: Evidence from China'stelecommunication industry Info, 4(6), pp. 50-60. 